\title{
DO OUTSIDE DIRECTORS FACE LABOR MARKET CONSEQUENCES? A NATURAL EXPERIMENT FROM THE FINANCIAL CRISIS
}

\author{
Steven M. Davidoff* \\ ANDREW C.W. LUND* \\ ROBERT SCHONLAU*
}

\begin{abstract}
The shock of the financial crisis focused shareholder and regulator attention on financial firm performance. We use the crisis as a lens through which to study labor market consequences for outside directors at banks and other financial firms. Examining 4,856 outside director-years at such institutions over the period from 2006 to 2010 , we find that the increased chance of being replaced for poor performance is between $1.22 \%$ and $5.79 \%$ for a one standard deviation change in performance, an arguably trivial amount. We also find no labor market reaction to poor firm performance in the form of lost directorship opportunities at other firms. We draw on these empirical findings to assess the limitations of board-centered responses to the financial crisis.
\end{abstract}

INTRODUCTION .................................... 54

I. Directors' Responsibility for the Financial Crisis ..... 56

A. Popular and Academic Criticism................ 56

B. The Regulatory and Quasi-Regulatory Push ......... 59

II. The Labor Market for Directors .................. 61

III. EMPIRICAL FINDINGS ............................. 64

A. Data Collection ........................... 64

B. Empirically Examining Director Turnover .......... 67

1. Outside Director Turnover ................ 67

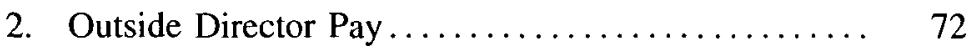

3. The Special Case of TARP ................. 75

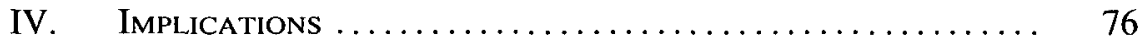

A. The Principal Case ......................... 77

B. The Pessimistic Case ........................ 79

C. The Case of Shareholder Forbearance ........... 82

Conclusion ...................................... 83

* Professor of Law and Finance, Moritz College of Law, Fisher College of Business (by courtesy), The Ohio State University. We thank Michal Barzuza, Lucian Bebchuk, Bernard Black, Brian Broughman, Jill Fisch, Jeffrey Gordon, Robert Jackson, Jr., Kate Litvak, A.C. Pritchard, Simone Sepe, Michael Weisbach, and participants at the 2013 American Law \& Economics Association Annual Meeting, Capital Markets Seminar at the Moritz College of Law, The Ohio State University and Maurer School of Law, Indiana University faculty workshop. We also thank Sneha Parmar and Russell Gray for excellent research assistance.

* Associate Professor of Law, Pace University School of Law.

* Assistant Professor of Finance, Brigham Young University, Marriott School of Management. 


\section{INTRODUCTION}

The results of the financial crisis are known to all: financial institutions sustained massive, sometimes all-consuming losses, and the larger economy fell into recession from which it is still struggling to recover. In the aftermath, outside directors of those financial firms have not fared well in many respects. In popular accounts, directors at Bear Stearns, Lehman Brothers, and other failed banks have been pilloried as negligent, naive, or both. They have been denounced for having played some causal role with respect to those firms' losses and the crisis more generally. In the post-crisis era, this view of outside directors has continued, and in early 2013 outside directors at JPMorgan Chase faced a threat to unseat them over their perceived inability to control the firm's risk-taking.

The central assumption behind this phenomenon is that outside directors substantively matter with respect to financial firm performance and risktaking. This assumption is often paired with the argument that if we give more power to outside directors they will enhance firm performance and prevent the next financial crisis. These ideas are seemingly taken on faith by regulators and lawmakers who have responded to the financial crisis by enhancing the supervisory role of outside directors at financial firms. The Dodd-Frank Act, for example, places outside directors as gatekeepers in monitoring financial institutions' systemic risk.'

But are these assumptions tenable?

This Article examines the propriety of regulatory reliance on outside directors to enhance financial firm performance and reduce risk-taking. It does so by examining whether shareholders and bank regulators have held directors accountable for poor performance before, during, and after the financial crisis. This question is important because, if the presumptions from outside director responsibility by the market and potential for improvement hold, one would expect shareholders and bank regulators to have removed these directors of their positions without further prodding. After all, remember kindergarten: when you did something wrong, you were punished. If directors function in the manner assumed by the regulatory response, one would expect they should also have been held responsible for their poor performance.

The salience of the financial crisis thus provides a platform to examine if ex post board-centered reform is attractive by looking to see if outside directors experienced past labor market penalties. In order to address this question, we examine 4,856 director-years at bank and financial companies over the period from 2006 to 2010 . The addition of observations before the financial crisis acts as a control to analyze whether outside directors at financial firms normally face penalties for poor performance. As a further check, we examine 45,772 outside director-years at non-bank, non-financial firms

\footnotetext{
${ }^{1}$ See infra note 34 and accompanying text.
} 
during the same period. To our knowledge, this is the only post-millennium study to directly examine the labor market for outside directors at financial firms as a function of general performance of the firms on whose boards they sit.

We find that there are negative turnover consequences for outside directors of financial firms that underperform their peers. Outside director turnover at such firms is negatively related to stock returns. However, the increased chance of being replaced given a one standard deviation decrease in firm performance is only between $1.22 \%$ and $5.79 \%$ depending upon our specifications. The average annual level of outside director turnover in the financial industry during and after the crisis was $6.53 \%$, less than half a percent higher than during the immediate period preceding the crisis. Our multivariate tests show that other factors, such as the outside director being 70 or older, are more significant predictors of director turnover than firm performance.

We further examine TARP recipients in particular, finding that entry into the program or delays in repayment did not negatively affect outside directors. We conclude by examining whether directors experience other penalties because of poor performance at their "home" firm. We do so by analyzing the incidence of other board membership as a function of "home" firm performance. One would expect that shareholders and regulators at other firms would penalize directors for poor performance, but we find no statistically significant correlation suggesting that they do so.

For a comparable sample of non-bank, non-financial firms, we also find that outside director turnover is negatively related to stock returns. The increased chance of being replaced given a one standard deviation decrease in firm performance for directors at non-financial firms is $0.68 \%$. Again, we find that a director reaching age 70 explains more of the likelihood of director turnover than firm performance.

Overall, although there is some evidence that outside directors faced labor market penalties after the crisis, they appear trivial. We conclude by discussing some tentative implications of our findings. Our results are consistent with the view that outside directors are largely inconsequential for firm performance and risk-taking and are particularly so in the context of complex modern financial firms. Alternatively, our results are consistent with the view that shareholders and regulators may not have been able to discipline outside directors despite believing outside directors' likely impact on firm performance. On this view, and in accordance with the arguments made for various director election reforms, there might be economically significant labor market consequences for poorly-performing directors if the costs of activism were lower. Finally, our results leave open the possibility that shareholders and regulators may have deliberately chosen not to discipline outside directors despite believing in their consequentiality.

These implications cut across each other, but, interestingly, each suggests a degree of skepticism about board-centered reform of the financial 
industry. At best, our finding of a limited director labor market means that board-centered reforms enacted in the wake of the financial crisis require a leap of faith that theories of outside director consequentiality are correct. Even then, advocates of board-centered reforms must grapple with the apparent absence of labor market discipline for those outside directors and offer reasons to expect improved director behavior in the absence of significant disciplinary sticks.

Our Article unfolds as follows: Part I reviews the popular, academic and regulatory views of outside director responsibility and the role of outside directors at firms, particularly financial firms before and during the crisis. Part II details prior academic study of the labor market for outside directors and its relevance for our study. Part III sets forth our empirical findings, while Part IV explores the sometimes competing implications from the dataset as it relates to board-centered financial reform and theories of the board more generally.

\section{Directors' Responsibility for the Financial Crisis}

We begin by outlining critical accounts of the role that outside directors played before and during the crisis at financial firms. In the view of many, boards and the outside directors that dominate them were central to the crisis, largely through sins of omission. ${ }^{2}$ The following is not meant to be exhaustive, as these views and the related regulatory responses have been discussed elsewhere. Our goal is simply to highlight the popular view of outside director responsibility in order to set the stage for our empirical study.

\section{A. Popular and Academic Criticism}

Outside directors figure prominently in popular accounts of the origins of the financial crisis. John Schnatter, the founder of Papa John's International, wrote in an influential Wall Street Journal op-ed that the financial crisis was caused by the failure of a "significant set of checks and balances-ultimately ending with the boards of directors." 3 Popular narratives of the collapse of AIG, Bear Stearns, Merrill Lynch, Citigroup, and Lehman Brothers portray boards of directors that are incompetent, dupes, cronyistic, or simply failures at properly supervising the corporate enterprise. ${ }^{4}$ More

\footnotetext{
${ }^{2}$ See infra Part I.A.

${ }^{3}$ John Schnatter, Op-Ed., Where Were the Boards?, WALL Sr. J., Oct. 25, 2008, at All.

${ }^{4}$ See, e.g., William D. Cohan, House of Cardds: A Tale of Hubris and Wretched Excess on Wall. Street 60 (2009); Bethany McLean \& Joe Nocrera, All. the Devils Are Here: The Hidden History of The Financial. Crisis 310 (2010); Lawrence G. McDonald \& Patrick Robinson, A Colossal Fallure or Common Sense: The Inside Story of thi: Collapse of Lehman Brothers 225-227 (2009); Roddy Boyd, Fatal Risk: A Cautionary Tale of AIG's Coriporate Suicide 123 (2011); Roger Lowensiein, The Enid of Wall. Street 106 (2010); Dennis K. Berman, Where Was Lehman's Board?, WAll St. J., Biogs
} 
recently, outside directors at JPMorgan Chase, one of the few firms to make it through the crisis relatively unscathed, were the subject of both intense criticism and an attempt to unseat them based on their perceived lax oversight of the bank's risk-taking. ${ }^{5}$ The idea that excessive bank risk-taking and the financial crisis were facilitated, if not caused, by idiosyncratic and institutional deficits in board-level corporate governance is one that has crept into the historical narrative of the crisis. ${ }^{6}$

Take for example William Cohan's book on Bear Stearns, A House of Cards. ${ }^{7}$ In Cohan's portrayal, Bear Stearns is the fiefdom of its Chairman and CEO Jimmy Cayne, who operates the financial institution without substantive board oversight. ${ }^{8}$ When the directors finally gather as the firm teeters on collapse searching for a rescue, the board cannot save the company and one of their first acts is to protect themselves from liability. ${ }^{9} \mathrm{Mr}$. Cohan's implicit conclusion is that the board failed to effectively function and properly supervise Mr. Cayne as well as the operations of Bear Stearns. The failures led to the investment bank's demise.

While these depictions in popular culture may be overstated, some more sober academics have joined in. They have produced a number of scholarly accounts that seek to confirm the story that boards not only failed, but did so in a way that helped cause or exacerbate the crisis and the resulting losses at financial firms. Most frequently, this scholarship suggests that boards failed to conduct proper risk oversight in the years leading up to the financial crisis. ${ }^{10}$ Relatedly, other scholars observe that boards made poor decisions with respect to compensation, operations, and investment at financial institutions. " When the crisis hit, some directors may have been more concerned with their own personal interests than those of their fiduciary ob-

(Sept. 15, 2008, 4:45 PM), http://blogs.wsj.com/deals/2008/09/15/where-was-lehmans-board/; Paul Myners, Banking Reform Must Begin in Boardroom, Fin. Times, Apr. 24, 2008, http:// www.ft.com/cms/82d60c06-1212-11dd-9b49-0000779fd2ac.html.

5 See Susanne Craig \& Jessica Silver-Greenberg, JPMorgan Directors Feel Heat in a Vote, N.Y. Times DealBook (May 3, 2013, 8:08 PM), http://dealbook.nytimes.com/2013/05/ 03/jpmorgan-board-feels-heat-from-upset-shareholders/? $r=0$.

${ }^{6}$ See, e.g., Schnatter, supra note 3; David Goldman, 'Goodbye and Good Riddance' AIG Directors!, CNNMONEY (June 30, 2009, 2:34 PM), http://money.cnn.com/2009/06/30/news/ companies/aig_shareholder_meeting/index.htm; J. Richard Finlay, Outrage of the Week: Leadership Fiddles While Bear Stearns Burns, FINLAy ON Governance (Mar 14, 2008), http:// finlayongovernance.com/? $\mathrm{p}=423$.

${ }^{7}$ See generally CoHAN, supra note 4 , at 60 .

${ }^{8}$ See id.; see also Kate Kelly, Bear CEO's Handling of Crisis Raises Issues, WaLl. ST. J., Nov. 1, 2007, Al (detailing Mr. Cayne's control over decision-making at the firm, including whether to sell Bear Stearns or not).

${ }^{9}$ See Cohnn, supra note 4 , at 60.

${ }^{10}$ See, e.g., Michael E. Murphy, Assuring Responsible Risk Management in Banking: The Corporate Governance Dimension, 36 DeL. J. CoRP. L. 121, 130-31 (2011).

"See, e.g., Kristin N. Johnson, Macroprudential Regulation: A Sustainable Approach to Regulating Financial Markets, 2013 U. Ill. L. Rev. 881, 891; Robert Sprague \& Aaron J. Lyttle, Shareholder Primacy and the Business Judgment Rule: Arguments for Expanded Corporate Democracy, 16 STAN. J.L. Bus. \& Fin. 1, 31-32 (2010). 
ligations. ${ }^{12}$ In sum, these accounts view the financial crisis and poor financial firm performance as consequences of corporate governance failure and particularly that of monitoring boards. ${ }^{13}$

As might be expected, this strain of literature has led to deeper critiques of board performance, particularly of outside directors. For those who think that outside directors are of questionable value, this has only provided confirmation. ${ }^{14}$ Other scholars have sought to rehabilitate these directors by pointing to their fixable deficits. In general, in this telling, boards failed at risk management inter alia because outside directors lacked appropriate incentives, expertise, or information. ${ }^{15}$ Alternatively, boards did not have the power, tools, or advisers to properly supervise and assess risk. Again, bad decisions were largely due to informational failures and asymmetries, failed incentives, or other fixable deficits at the director level. ${ }^{16}$ Often, these critiques revert to arguing that if boards had been more independent of management, they might have questioned executives more and been more successful in both their monitoring and managerial roles. ${ }^{17}$

Not surprisingly, the solution in these accounts is to enhance outside director power, independence, and accountability. Thus, academics have proposed that certain legal standards be revised to incentivize outside directors to further supervise the risk management of the company ${ }^{18}$ and to have some level of expertise in such matters. ${ }^{19}$ Legal liability standards are to be

${ }^{12}$ See CoHan, supra note 4, 109-10.

${ }^{13}$ The narrative has mixed support in the available empirical evidence. See Brian R. Cheffins, Did Corporate Governance "Fail" During the 2008 Stock Market Meltdown? The Case of the $S \& P$ 500, 65 Bus. LAw. 1, 3-4 (2009) (finding corporate governance generally did not fail during the stock market meltdown); see also Rene Stulz \& Rudiger Fahlenbrach, Bank CEO Incentives and the Credit Crisis, 99 J. FiN. ECON. 11, 15-16 (2011) (finding some correlation between shareholder-friendly compensation arrangements and poor performance during the crisis).

${ }^{14}$ See generally Cohan, supra note 4; John C. Coffee, Jr, What Went Wrong? An Initial Inquiry into the Causes of the 2008 Financial Crisis, 9 J. Corp. L. STud. 1 (2009); Craig \& Silver-Greenberg, supra note 5; Finlay, supra note 6; Goldman, supra note 6; Murphy, supra note 10; Schnatter, supra note 3; Sprague \& Lyttle, supra note 11.

${ }^{15}$ See, e.g., Manns, infra note 17; see also Cunningham, infra note 19; Jones \& Welsh, infra note 20; Pan, infra note 18.

${ }^{16}$ See Nicola Faith Sharpe, Rethinking Board Function in the Wake of the 2008 Financial Crisis, 5 J. Bus. \& Tech. L. 99, 110 (2010); see also Lucian A. Bebchuk \& Holger Spamann, Regulating Bankers' Pay, 98 GEo. L.J. 247, 255 (2010).

${ }^{17}$ See, e.g., Jeffrey Manns, Building Better Bailouts: The Case for a Long-Term Investment Approach, 63 FLA. L. REv. 1349, 1392 (2011). Indeed, this is the basic theme of the recent proxy fight at JPMorgan Chase and the unsuccessful attempt to separate the CEO and Chairman positions there. See, e.g., Andrew Johnson, Vote on J.P. Morgan Chairman, CEO Roles Expected to Be Close, WAL_. Sr. J., May 20, 2013, http:/online.wsj.com/news/articles/ SB10001424127887324787004578495363901394952 (citing activist view that "[h]aving separate people in the roles allows for more checks and balances that can better identify conflicts of interest").

${ }^{18}$ See, e.g. Eric J. Pan, Rethinking the Board's Duty to Monitor: A Critical Assessment of the Delaware Doctrine, 38 FlA. St. U. L. Rev. 209, 225-31 (2011).

${ }^{19}$ See, e.g., Lawrence A. Cunningham, Rediscovering Board Expertise: Legal Implications of the Empirical Literature, 77 CinCINNATI L. Rev. 465, 467 (2008). 
enhanced to similarly push boards to conduct prudent oversight. ${ }^{20}$ Other accounts have argued for greater federal intervention to erect structures that ameliorate observed behavioral deficits of boards and directors. ${ }^{21}$

Interestingly, while potential liability incentives have been front and center, outside directors' labor market incentives are often unaddressed in these academic accounts. If directors are blameworthy, labor market penalties-either loss of board seats or reduced compensation-would seem to be at least useful complementary devices. ${ }^{22}$ This assumption is sometimes made explicit by proposals, such as proxy access, to empower long-term shareholders to somehow discipline short-term oriented directors. ${ }^{23}$ The failure to discuss labor market incentives may simply reflect pessimism on reformers' parts regarding the outside director labor market, ${ }^{24}$ or even distrust of shareholders. ${ }^{25}$ But, for our purposes, it is nonetheless worth noting that attempts to enhance labor market discipline have been largely absent from boardcentered reform proposals. ${ }^{26}$

\section{B. The Regulatory and Quasi-Regulatory Push}

Similar arguments have driven corporate governance regulation (and preludes to regulation) after the financial crisis. For instance, ${ }^{27}$ in 2009 U.K. Prime Minister Gordon Brown charged David Walker with examining corporate governance in the banking industry. ${ }^{28}$ Walker's report, delivered later

${ }^{20}$ See Renee M. Jones \& Michelle Welsh, Toward a Public Enforcement Model for Directors' Duty of Oversight, 45 VAND. J. TRAnSNaT'L. L. 343, 370 (2012).

${ }^{21}$ See Kristen N. Johnson, Addressing Gaps in the Dodd-Frank Act: Directors' Risk Management Oversight Obligations, 45 U. MiCH. J.L. REFORM 55, 66 (2011). These board-centered responses count as the lion's share of reform proposals outside the realm of enhanced prudential regulation.

${ }^{22}$ There may, however, be reasons to think financial firm shareholders have divergent preferences vis-à-vis regulators with respect to risk management. See id. at 110 .

${ }^{23}$ See Lynne L. Dallas, Short-Termism, the Financial Crisis, and Corporate Governance, 37 J. CorP. L. 265, 353 (2012); Christopher M. Bruner, Corporate Governance Reform in a Time of Crisis, 36 J. CoRP. L. 309, 321 (2011). Alternatively, shareholders should not be empowered under the assumption they currently lack significant ability to influence the firm. See William M. Bratton \& Michael Wachter, The Case Against Shareholder Empowerment, 158 U. PA. L. REV. 653, 658, 690 (2010).

${ }^{24}$ See, e.g., Lucian Bebchuk \& Scott Hirst, Private Ordering and the Proxy Access Debate, 65 Bus. LAw. 329, 335 (2010); see also infra notes 70-72 and accompanying text.

${ }^{25}$ See, e.g., William W. Bratton \& Michael L. Wachter, The Case Against Shareholder Empowerment, 158 U. PA. L. Rev. 653, 661-62 (2010).

${ }^{26}$ But see Jeffrey Gordon, Executive Compensation and Corporate Governance in Financial Firms: The Case for Convertible Equity-Based Pay 9 (Columbia Law Sch. \& European Corporate Governance Inst., Working Paper No. 373, 2010), available at http://papers.ssrn. $\mathrm{com} / \mathrm{sol} 3 /$ papers.cfm?abstract_id $=1633906$.

${ }^{27}$ There are other examples. See, e.g., Grant KirkPatrick, OECD Stefining Group on Corporate Govirnance, The Corporate Governance Lessons from the Financial CriSIS (2009) available at http://www.oecd.org/daf/corporateaffairs/corporategovernanceprinciples/42229620.pdf.

${ }^{28}$ See, e.g., Sir David Wal.Ker, A Review of Corporate Governance in UK Banks and Other Financial Industry EnTtries (Nov. 16, 2009), available at http://webarchive. nationalarchives.gov.uk/+/http:/www.hm-treasury.gov.uk/d/walker_review_261 109.pdf. 
that year, was almost entirely focused on board failures and board-related remedies:

The most critical need is for an environment in which effective challenge of the executive is expected and achieved in the boardroom before decisions are taken on major risk and strategic issues. For this to be achieved will require close attention to board composition to ensure the right mix of both financial industry capability and critical perspective from high-level experience in other major business. It will also require a materially increased time commitment from non-executive directors (NEDs), from whom a combination of financial industry experience and independence of mind will be much more relevant than a combination of lesser experience and formal independence. ${ }^{29}$

Beyond these basic structural changes, the Walker Report points to the need for increased board oversight of risk management ${ }^{30}$ and compensation practices $^{31}$ along with board engagement with long-term shareholders. ${ }^{32}$

U.S. post-crisis regulation has also followed the trend toward boardcentered reform. The Dodd-Frank Wall Street Reform and Consumer Protection Act ("Dodd-Frank Act") provides for the creation of risk management supervision committees comprised of independent directors with at least one expert in risk management among them. ${ }^{33}$ It requires disclosure regarding the separation of the board chairman and CEO positions. ${ }^{34}$ The Act also provides for proxy access, presumably in order to enhance the labor market for directors. ${ }^{35}$ Disclosure obligations are also added in order to provide for greater transparency of decision-making. ${ }^{36}$

We do not detail every example here, but note that enhancing the power of outside directors had become a commonly-used regulatory technique in the United States by lawmakers, regulators, and the exchanges long before the recent crisis. ${ }^{37}$ This trend has simply continued in post-crisis criticisms and reforms. The net result is that directors, particularly outside directors,

${ }^{29} \mathrm{Id}$. at 12 .

${ }^{30} \mathrm{Id}$. at $90-105$.

${ }^{31} \mathrm{ld}$. at $106-26$.

${ }^{32}$ Id. at $68-89$.

${ }^{33}$ The requirement is for all public bank holding companies and public non-bank financial holding companies supervised by the Federal Reserve with assets of $\$ 10$ billion or greater. Dodd-Frank Wall Street Reform and Consumer Protection Act Pub. L. No. 111-203, \$165, 124 Stat. 1376 (2010) [hereinafter Dodd-Frank Act].

${ }^{34} I d$. $\$ 972$.

${ }^{35}$ Id. $\$ 971$.

${ }^{36}$ Specifically, the new disclosure obligations center on compensation matters, potentially increasing transparency into management incentives. $I d$. $\$ \S 953,955$.

${ }^{37}$ See, e.g., The Sarbanes-Oxley Act of 2002, Pub.L. No. 107-204, \$301, 116 Stat. 745 , enacted July 30, 2002 (requiring public companies to have audit committees comprised of independent directors); $I d$. $\$ 165$ (h) (requiring certain public financial companies and bank holding companies to have risk committees comprised of independent directors). 
have emerged as a putatively more powerful and independent monitoring organ in post-financial crisis corporate governance. ${ }^{38}$

\section{The Labor Market for Directors}

How should observers feel about these board-centered accounts of financial failure and reform? As discussed below, some cast serious doubt on the ability of boards of financial firms to impact things such as risk management and general firm performance. On the other hand, it makes certain intuitive sense to lay a measure of responsibility for the crisis on financial firm boards and seek board reform as a regulatory response. Ultimately, though, without more data it is hard to know exactly how much board failures contributed to the problems and how much should be expected of "fixing" financial firm boards now.

Our project is designed to indirectly address this central question of board responsibility for the crisis. We explore whether shareholders and regulators ${ }^{39}$ imposed labor market discipline on boards in the wake of the crisis for poor financial firm performance. If we observe such discipline, the argument for outside directors' consequentiality for financial firm performance is enhanced, and board-centered responses become more sensible. If we observe no discipline, then it may be that (1) the director labor market is not functioning, a failure that any board-centered reform must address; (2) arguments that outside directors are irrelevant for firm performance find support, throwing into question the post-crisis focus on financial firm boards generally; or (3) shareholders and regulators chose not to act for other reasons. Each explanation, however, places board-centered reform in a more skeptical light, as proponents must explain what will be different in the future.

Almost thirty years ago, Fama and Jensen suggested that outside directors should expect future labor market consequences as a result of their performance as monitors. ${ }^{40}$ Surprisingly, since that time, the vast literature on the role of outside directors has failed to empirically show whether the labor market works to discipline outside directors for general performance of the firms on whose boards they serve. ${ }^{41}$ The studies that have been conducted examine director turnover following transformational events. These studies

38 See Paul Rose, Regulating Risk by "Strengthening Corporate Governance," 17 ConN. INs. L.J. 1, 7-10 (2010).

${ }^{39}$ Due to their unique regulatory position, bank boards are subject to discipline by regulators as well as shareholders. See generally Richard SCOTT CARNELL, ET AL., THE LAW of Banking and Financial Instrtutrons, at 693-737 (4th ed. 2009).

${ }^{40}$ See Eugene Fama \& Michael Jensen, The Separation of Ownership and Control, $26 \mathrm{~J}$. L. \& ECON. 301, 315 (1983) ("[Outside directors] use their directorships to signal to internal and external markets for decision agents that . . they understand the importance of diffuse and separate decision control, and ... they can work with such decision control systems.").

${ }^{41}$ Lucian Bebchuk and Jesse Fried have expressed skepticism about whether the reputation market for directors provides the kind of strong incentives that Fama and Jensen hypothesize. See generally Lucian Bebchuk \& Jesse Fried, Pay without Performance: The Unfulfilled Promise of Executive Compensation (2006) 
observed high levels of outside director turnover in the context of debt defaults ${ }^{42}$ and the acquisition of firms. ${ }^{43} \mathrm{~A}$ number of studies have also looked at the correlation between securities fraud and subsequent outside director turnover, albeit with somewhat conflicting results. ${ }^{44}$ Finally, directors who fail to opt out of state anti-takeover laws appear to be penalized by receiving fewer future board opportunities. ${ }^{45}$

As far as general firm performance goes, there is some evidence that the performance of a firm at which one served as an executive corresponds with the number of that executive's subsequent outside director opportunities. ${ }^{46}$ On the other hand, there is relatively little scholarship detailing the general relationship between the performance of the firm at which one served as a director and that director's subsequent success in the labor market. Ferris, Jagannathan, and Pritchard, studying the relationship between multiple directorships and later firm performance, find that outside directorships are likely a reward for firm performance at previous appointments. ${ }^{47}$ The authors provide data for all directors, using the average performance for directors who are not executives, and performance by the "home" firm for directors who are executives, and also for the subset of directors who are executives. ${ }^{48}$ Although they find significant positive correlation between past firm performance and future directorships, ${ }^{49}$ they did not produce any findings limited strictly to outside directors. Without such data, it might be that

${ }^{42}$ See Stuart C. Gilson, Bankruptcy, Board, Banks and Blockholders: Evidence on Changes in Corporate Ownership and Control When Firms Default, 27 J. FIN. Econ. 355 (1990).

${ }^{43}$ See Jarrad Harford, Takeover Bids and Target Directors' Incentives: The Impact of a Bid on Directors' Wealth and Board Seats, 69 J. FIN. ECON. 51, 62 (2003).

${ }^{44}$ See, e.g., Anup Agrawal, Jeffrey F. Jaffe \& Jonathan M. Karpoff, Management Turnover and Governance Changes Following the Revelation of Fraud, 42 J.L. \& ECoN. 309, 334 (1999) (no significant outside director turnover following fraud charges); Eliezer M. Fich \& Anil Shivdasani, Financial Fraud, Director Reputation and Shareholder Wealth, 86 J. Fin. Econ. 306, 334-35 (2007) (finding no significant outside director turnover following fraud law suits even though directors did face significant loss of other board seats); Eric Helland, Reputational Penalties and the Merits of Class-Action Securities Litigation, 49 J.L. \& ECON. 365, 378-79 (2006) (noting outside directors experience labor market penalties only when settlement amount of fraud allegations is in top quartile of settlements or when fraud cases are brought by the SEC); Suraj Srinivasan, Consequences of Financial Reporting Failure for Outside Directors: Evidence from Accounting Restatements and Audit Committee Members, J. Accr. Res. 291, 293 (2005) (finding significant labor market consequences for outside directors, particularly audit committee members, following earnings restatements).

${ }^{45}$ See Jeffrey L. Coles \& Chun-Keung Hoi, New Evidence on the Market for Directors: Board Membership and Pennsylvania Senate Bill 1310, 58 J. Fin. 197, 229 (2003).

${ }^{46}$ See James A. Brickley, James S. Linck \& Jeffrey L. Coles, What Happens To CEOs After They Retire? New Evidence on Career Concerns, Horizon Problems, and CEO Incentives, 52 J. Fin. Econ. 341, 360 (1999); Steven N. Kaplan \& David Reishus, Outside Directorships and Corporate Performance, 27 J. OF FIN. ECon. 389, 400-03 (1990).

${ }^{47}$ Stephen P. Ferris, Murali Jagannathan \& A.C. Pritchard, Too Busy to Mind the Business? Monitoring Directors with Multiple Board Appointments, 58 J. Fin. 1087, 1099-100 (2003).

${ }^{48} l d$. at 1090 .

${ }^{49}$ Id. at 1099 . 
the director labor market is sensitive to past executive performance, but not past director performance.

Fich and Shivdasani, while challenging the work by Ferris, et al. on unrelated grounds, ${ }^{50}$ similarly find a positive correlation between performance of firms at which one was associated and future directorships. ${ }^{51}$ Fich and Shivdasani, however, also evaluate past firm performance for executivedirectors using performance by "executive" firms making it difficult to tease out labor market consequences experienced by virtue of "outside director" firms. Equally important for our purposes, they exclude financial firms from their analysis. ${ }^{52}$

Finally, Yermack comes closest to addressing the question we ask insofar as the relevant performance measure he uses is exclusively the performance of firms on whose board the person served as an outside director. ${ }^{53}$ Looking at the incentives facing outside directors, he observed a significant association between outside director turnover and firm performance. ${ }^{54}$ However, this association was not economically significant. ${ }^{55}$ And, interestingly, the relationship between firm performance and director turnover was far more attenuated than the relationship between firm performance and CEO turnover. ${ }^{56}$ Yermack also found that outside directors at highly performing firms achieved other outside directorships at higher rates than others, at least under certain specifications. ${ }^{57}$ Like Fich and Shivdasani, though, Yermack excluded financial firms from his dataset. ${ }^{58}$ Moreover, Yermack's study covers a period over a decade prior to the one we study: ${ }^{59}$ one in which shareholder power and the salience of firm performance may have been significantly less than the power and salience of those during the crisis.$^{60}$

The goal of our study is thus to analyze whether the labor market penalizes outside directors at poorly performing financial firms. We do so using the financial crisis as a ripe moment for discipline when shareholders, regu-

${ }^{50}$ See Eliezer M. Fich \& Anil Shivdasani, Are Busy Boards Effective Monitors?, J.Fin. 689,694 (2006) (questioning Ferris, et al.'s (1) use of cross-sectional regressions of market-tobook ratios without controlling for growth opportunities, (2) failure to use fixed-effects regressions, and (3) proxy choices for "busy boards"). In particular, they find that "busy" boards are worse monitors than non-busy ones, contrary to Ferris, et al.'s findings.

${ }^{51}$ See id. at 708.

${ }^{52}$ See id. at 696.

${ }^{53}$ David Yermack, Remuneration, Retention and Reputation Incentives for Outside Directors, 59 J. FIN. 2281, 2283 (2004).

${ }^{54} \mathrm{Id}$. at $2294-96$.

s5 Id. at 2297.

${ }^{56} I d$. at 2296.

${ }^{57} I d$. at 2302 (finding significant results only when using a lagged performance variable and stock return measures).

${ }^{58} \mathrm{Id}$. at 2283.

${ }^{\text {s9 }}$ See Yermack, supra note 53, at 2282.

${ }^{60}$ See Jarrad Harford \& Robert J. Schonlau, Does the Director Labor Market Offer Ex Post Settling-up for CEOs? The Case of Acquisitions, 110 J. Fin. ECON 18, 28 (2013) (finding that directors with successful acquisition experience go on to have better success in the director labor market). 
lators, and other corporate participants were likely to more closely scrutinize financial firms' management, including outside directors. In doing so, we hope to provide a firmer base from which to draw conclusions regarding the role of outside directors in financial firms and the related issue of effective regulation of such firms.

\section{Empirical Findings}

\section{A. Data Collection}

We begin by collecting financial firm director-years (along with start/ end years and compensation data) using Execucomp's database from the period 2006 through 2010. We use available 2011 data from Execucomp for the sole purpose of examining whether outside directors experienced turnover during 2010. S\&P 1500 firms are classified as financial firms using SIC codes. Approximately two-thirds of the resulting financial firm directoryears correspond to directors of commercial banks or SIC Codes 6021-6029. The remaining one-third include directors at, among others, savings institutions (federally chartered and not), securities and commodities brokers, and securities broker-dealers.

We then match those years with director characteristics using the RiskMetrics database including gender, age, years of service, insider/outsider status, and other major public directorships held. We also control for firm size and firm performance using data from Compustat and CRSP. Finally, we also code for Troubled Asset Repurchase Program (TARP) participation using data disclosed by the Treasury Department in their monthly reports to Congress on the status of TARP. We drop director-years where one or another kind of data is missing. ${ }^{61}$ This leaves us with 612 financial firm years and 6,825 director year observations. We perform similar data collection for non-bank, non-financial firms in the S\&P 1500 to arrive at a sample of 6,691 firm years and 56,621 director-years at non-bank, non-financial firms during the same period.

${ }^{61}$ The total number of director-years dropped for missing director data is 202 or about $3 \%$ of our sample, an amount that we do not think materially drives our results. We drop an additional 445 director-years where a director is at a firm in year $t$ but the firm does not exist in our sample in year $t+1$. Because we do not treat directors at firms that exist in our sample in year $t$ but not in $t+l$ as having turned over, our data may undercount director discipline that would have occurred absent dissolution or takeover and director turnover that occurs at firms covered differently by the Riskmetrics and Execucomp databases. We do not count directors at acquired or bankrupt firms (i.e., $t+l$ firms) as turned over because we cannot know what existing shareholders would have done to such directors in the absence of the takeover or bankruptcy. Because firms that drop from the data tend to be underperforming, we recognize that we may be undercounting labor market sensitivity insofar as our sample is skewed towards high-performing firms. We discuss the implications of this coding decision in Section III.B below. 


\section{Sample Descriptive Statistics}

Table 1 presents descriptive statistics concerning all of the financial firm directors in our sample.

\section{Table 1: Characteristics of Observations of Financial Firm} Directors in SAMPLE

\begin{tabular}{rcccccccc}
\hline Year & $\begin{array}{c}\text { Number } \\
\text { of firms }\end{array}$ & $\begin{array}{c}\text { Number } \\
\text { of } \\
\text { directors }\end{array}$ & $\begin{array}{c}\text { Number } \\
\text { of } \\
\text { outsiders }\end{array}$ & $\begin{array}{c}\text { Number of } \\
\text { directors } \\
\text { with } \\
\text { financial } \\
\text { experience }\end{array}$ & $\begin{array}{c}\text { Number } \\
\text { of female } \\
\text { directors }\end{array}$ & $\begin{array}{c}\text { Number } \\
\text { of first } \\
\text { years }\end{array}$ & $\begin{array}{c}\text { Number } \\
\text { of last } \\
\text { years }\end{array}$ & $\begin{array}{c}\text { Number } \\
\text { of } \\
\text { outsider } \\
\text { last years }\end{array}$ \\
\hline 2006 & 128 & 1,331 & 1,006 & - & 163 & 88 & 90 & 75 \\
2007 & 128 & 1,433 & 1,148 & - & 170 & 110 & 69 & 55 \\
2008 & 119 & 1,342 & 1,073 & 231 & 164 & 77 & 86 & 70 \\
2009 & 121 & 1,402 & 1,120 & 254 & 183 & 90 & 109 & 85 \\
2010 & 116 & 1,317 & 1,068 & 239 & 170 & 71 & 83 & 58 \\
\hline Total & 612 & 6,825 & 5,415 & 792 & 850 & 436 & 437 & 343 \\
\hline
\end{tabular}

Of those director-years, 5,415 were outside director-years. Illustrating the dominance of independent directors in modern board composition, the numbers imply a mean board size of 11.15 directors, with an average of almost nine independent directors. These financial firm boards were much larger than non-financial firm boards that, in statistics not reported in Table I, had an average of 8.46 directors of whom on average 6.83 were outside directors. An average of approximately $18 \%$ of all financial firm directors had financial experience and $12.45 \%$ were female. For all directors, the turnover rate was $6.40 \%$ and, for outside directors only, the turnover rate was $6.33 \%$. These rates imply an average tenure as an outside director at a financial institution of 15.8 years. ${ }^{62}$ For non-financial firms, the general turnover rate was $6.12 \%$ and the outside-director-specific turnover rate was $6.08 \%$.

Table 2 sets forth key characteristics of the sample for financial firms and outside directors. On average, $14.46 \%$ of outside directors were female while the median number of outside female directors was zero. The skewness reflects that, consistent with prior studies, certain boards tend to appoint more outside female directors. ${ }^{63}$ Women made up a slightly higher percentage of directors-14.68\% - at non-financial firms than financial firms in our study. Reflecting regulatory requirements for independent directors on audit

${ }^{62}$ If we included as "turned over" the directors in the sample in year $t$ at firms that disappear from the sample in year $t+l$, then the turnover rate would increase and the implied tenure would decrease.

${ }^{63}$ See Renee B. Adams \& Daniel Ferreira, Women in the Boardroom and Their Impact on Governance and Performance, 94 J. FIN. ECON. 291, 294-95 (2009); Kathleen A. Farrell \& Philip L. Hersch, Additions to Corporate Boards: The Effect of Gender, 11 J. CORP. Fin. 85, 99 (2005). 
Table 2: Key Characteristics of Sample (Financial. Firm/Outside DiRECTORS ONLY)

\begin{tabular}{|c|c|c|}
\hline & mean & median \\
\hline Female & $14.46 \%$ & $0.00 \%$ \\
\hline Age & 63.03 & 64.00 \\
\hline Shares held/shares outstanding & $0.22 \%$ & $0.03 \%$ \\
\hline Number of shares held (thousands) & 210.12 & 34.96 \\
\hline Other board seats & 0.59 & 0.00 \\
\hline Audit committee member & 0.36 & 0.00 \\
\hline Compensation committee member & 0.35 & 0.00 \\
\hline Classified board & 0.59 & 1.00 \\
\hline Revenue ( $\$$ millions) & $\$ 7,514.16$ & $\$ 715.76$ \\
\hline Stock return net of market (prior year) & -0.07 & -0.09 \\
\hline Stock return net of market (prior 2 years) & -0.06 & -0.08 \\
\hline \multicolumn{3}{|l|}{ Board Compensation ( $\$$ thousands) } \\
\hline Cash fees & 63.81 & $\$ 59.25$ \\
\hline Stock awards & 50.24 & $\$ 24.02$ \\
\hline Options awards & 12.22 & $\$ 0.00$ \\
\hline Non-equity incentive plan & 0.09 & $\$ 0.00$ \\
\hline Change in pension value & 1.67 & $\$ 0.00$ \\
\hline Other compensation & 5.46 & $\$ \quad 0.00$ \\
\hline Total compensation & $\$ 133.19$ & $\$ 108.90$ \\
\hline
\end{tabular}

and compensation committees, an average of $35 \%$ of outside directors were members of their firm's compensation committee and on average $36 \%$ of outside directors were members of their firm's audit committee. The median outside director did not sit on another firm's board, and the average outside director had 0.59 seats on another board with approximately $10 \%$ of outside directors holding two or more additional board seats. This deviated from outside directors at non-financial firms who held an average of .995 seats on other boards with approximately $17 \%$ of outside directors holding two or more additional board seats. In addition, the average financial firm director was sixty-three years old with a median age of sixty-four, implying that most directors are in the later stage of their careers. Stock returns are mean and median buy and hold returns during the period, and reflect the financial crisis with the mean stock market return net of the market return for the sample at $-6 \%$ with a median of $-8 \%$.

The table also shows that mean financial firm director compensation consists of equal parts cash and incentive compensation. The mean total annual compensation for outside directors in the sample was $\$ 133,190$, with the average director receiving $\$ 62,460$ in stock and option incentive compensation. The median equity award was $\$ 24,020$ for stock incentives and 
zero for options, however, implying that the distribution is skewed. ${ }^{64}$ Certain companies are more likely to not only award stock and options, but also to do so in significantly larger amounts than average. At non-financial firms, average pay was $\$ 180,249$ and a higher proportion (approximately $56.61 \%$ as opposed to $46.89 \%$ in financial firms) came from equity awards (including options) than cash.

\section{B. Empirically Examining Director Turnover}

\section{Outside Director Turnover}

Our first empirical goal is to examine the statistical and economic significance of financial firm performance for outside director turnover. We begin in Chart I by examining descriptive statistics concerning background turnover rates in our data on a year-by-year basis. ${ }^{65}$

Chart I: Financial Firm Director Turnover on a YEAR-BY-YEAR BASIS

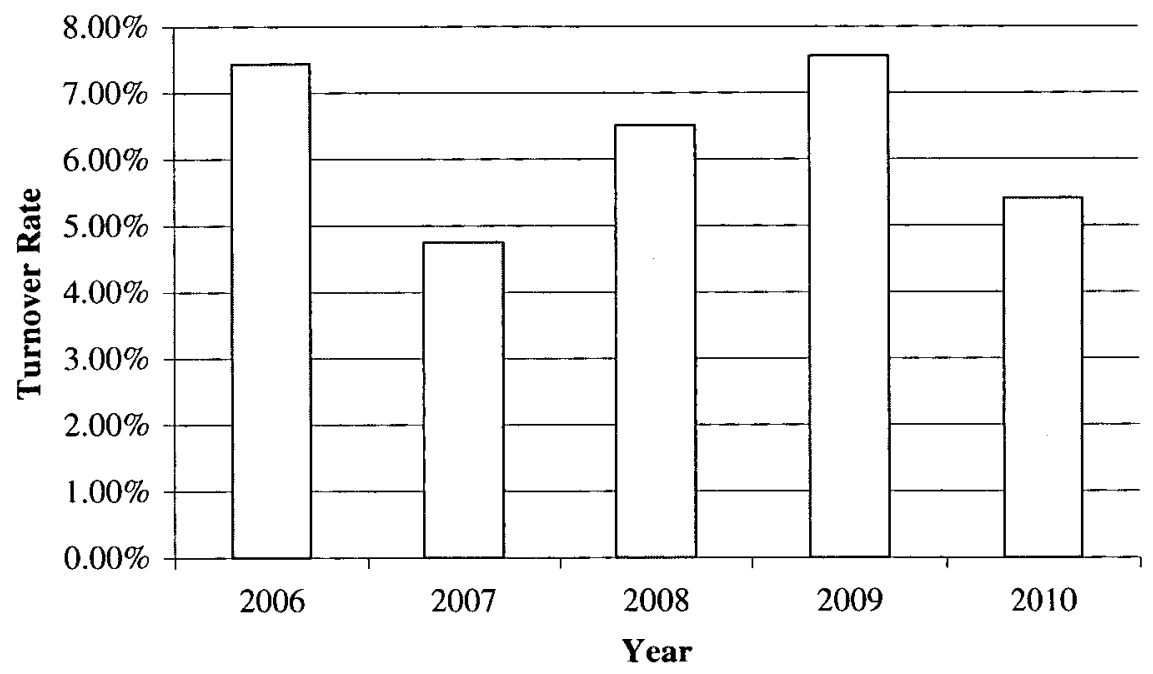

Chart I shows that outside directors at financial firms experienced their highest number of "final years" in 2006, 2008, and 2009 with a turnover rate of $7.46 \%, 6.52 \%$, and $7.59 \%$, respectively. This compares with reduced

${ }^{64}$ The trend toward awarding more restricted shares than stock options is consistent with David Walker's recent study. See David I. Walker, Evolving Executive Equity Compensation and the Limits of Optimal Contracting, 64 VAND. L. REv. 611,632 (2011).

${ }^{65}$ As noted, "turnover" indicates that a director was in the company's proxy in that year but not the following one. Generally, this would require that they ceased being a director whether by losing a contested election in the first year, resigning during the interim, or failing to be nominated by the company in the second year. 
rates of $4.79 \%$ in 2007 and $5.43 \%$ in 2010 . Grouping pre- and post-financial crisis periods together, outside directors at financial firms experienced aggregate turnover of $6.04 \%$ in the $2006-07$ pre-crisis period and $6.53 \%$ turnover in the 2008-10 post-crisis period. ${ }^{66}$

The figures imply that there was a slight uptick in financial firm board turnover in the post-financial crisis period. If we assume instead that any discipline was quickly meted out for crisis-related failures and remove 2010 turnover, the difference between pre- and post-crisis periods increases from $0.49 \%$ to $1.03 \%$. On the other hand, if we assume that discipline occurred only through shareholder voting after the Spring/Summer 2009 proxy season, then the pre-/post-crisis difference in turnover rates shrinks to $0.34 \%$.

Of course, the inference that the uptick in turnover implies enhanced board discipline is merely that and may be due to other variables. In order to further examine the significance of the descriptive statistics in Chart I, and to further determine if the turnover is related to market performance, in Table 3 we explore director turnover versus financial firm performance in a multivariate setting.

We conduct a logit regression of outside director turnover controlling for years of service as director at the firm, age between sixty-five and sixtynine, age greater than or equal to seventy, percent ownership, gender, audit and compensation committees, presence or absence of a classified board, whether the year in question corresponds with the CEO departing, whether the CEO that appointed the director is still CEO, and stock performance at the firm net of the market. We further break the results into two columns in order to assess turnover over two performance periods. Column 1 assesses turnover over a one-year period of stock returns while Column 2 does so over the preceding two years of stock returns. ${ }^{67}$

The variable with the largest significant coefficient is a director reaching age seventy, rather than poor performance. However, we also find a statistically significant correlation between turnover and firm performance, when the latter is measured by stock returns net of market over either the immediately prior year or the prior two years, each at the five percent level. This is consistent with the notion that outside directors experience greater discipline following poor performance. This finding is also consistent with Yermack's finding that outside director turnover is negatively and significantly correlated with firm performance. ${ }^{68}$ In unreported regressions, we examine whether the financial crisis itself produced an increase in turnover by including an indicator variable for the crisis year, but we do not find any statistically significant results.

${ }^{66}$ Fluctuations were wilder for outside directors at financial firms than those at non-financial firms. In the latter case, the high water mark for tumover came in 2008 with a rate of $6.18 \%$, while the lowest level of turnover was in 2009 at $5.68 \%$.

${ }^{67}$ These variables are similar to those utilized in Yermack's study. See Yermack, supra note 53 , at 2297 . We also add a classified board control.

${ }^{68}$ Id. at $2296-97$. 
Table 3: Director Turnover versus Performance at FinANCIAL Firms

(1)

Stock return net of market (prior year)

$-0.316^{* * *}$

$(0.008)$

Stock return net of market (prior 2 years)

$-0.384^{* * *}$

Firm size

$0.112^{* *}$

$(0.006)$

$(0.044)$

$0.108^{*}$

Years of service

$-0.000$

$(0.058)$

Years of service

(0.999)

0.001

Age 70 and over indicator

$1.458^{* * *}$

(0.946)

Shares held/shares outstanding

$(0.000)$

$1.448^{* * *}$

$-6.569$

(0.000)

Constant

(0.209)

$-6.675$

$-3.652 * * *$

(0.197)

Observations
Pseudo R-squared

$(0.000)$

$-3.625^{* * *}$

4856

$(0.000)$

Note: The logit models in Table 3 include the following non-tabulated controls: years of service and indicators for year, if the director's age is between 65 and 69 , female, audit committee member, compensation committee member, classified board, and whether the appointing CEO is no longer in office. P-values are shown below the logit coefficients with errors clustered at the firm level.

In both cases, the economic significance of this increased discipline is uncertain. To facilitate interpretation of the results, we use the model in Column 1 to calculate the predicted probability of turnover under two scenarios: firm performance either one-half standard deviation below mean performance or one-half standard deviation above mean performance. The predicted probability of turnover in a given year is $6.17 \%$ for an outside director at a firm with poor performance and $4.95 \%$ for an outside director at a firm with good performance. Thus, a large change of one standard deviation in firm performance is associated with a $1.22 \%$ change in the likelihood of outside director turnover, a seemingly insignificant economic amount. ${ }^{69}$

In our database, directors are dropped from a firm year if the firm is no longer included in the sample in the following year. A firm can be dropped if it is acquired or goes bankrupt, another form of potential market discipline. Forty-seven firms are dropped during our sample time period. Of those firms, thirty-two were acquired by other firms, including Bear Stearns, and fifteen went through bankruptcy or a similar reorganization, including Lehman Brothers.

${ }^{69}$ See id. at 2299 (noting that a $2.2 \%$ change in turnover probability based on one standard deviation difference in performance is "modest"). 
As a robustness check, we assume all directors at firms that were acquired or went bankrupt would have turned over. In that case, performance one-half standard deviation below the mean predicts a $15.77 \%$ turnover rate, while performance one-half standard deviation above the mean predicts a $9.98 \%$ turnover rate. The $5.79 \%$ increase is larger than the $1.22 \%$ increase we see in the earlier specification, and may be economically significant.

However, the actual significance of this is indeterminate. In the case of an acquisition, this may be a desired outcome for directors because it allows shareholders to exit the firm at a premium. Alternatively, the takeover market may be disciplining these outside directors by wresting control from poorly performing managers. Certainly, bankruptcy is its own form of discipline, and directors lose their jobs, but this is not a form of shareholder discipline. Of course, it is possible that shareholders would have disciplined outside directors at failing firms but for the bankruptcy intervention. On the other hand, shareholders would not have disciplined all outside directors at all such firms. Thus, implied turnover in our dataset is bounded by $1.22 \%$ on the low end and $5.79 \%$ on the high end. Exactly where within that range implied shareholder discipline lands requires making an assumption about what shareholders or regulators would have done but for the event that caused the firm to be dropped from our sample. ${ }^{70}$ We further discuss the significance of this data in Section IV below.

If directors have existing relationships with CEOs, then this theoretically would also drive director turnover. We are able to replicate the finding in Yermack which correlates the appointing CEO leaving office and outside director turnover, but only at the $10 \%$ level. ${ }^{71}$ Our analysis is run during a more recent time period compared to Yermack's study, so this may indicate that CEOs have marginally less control over the outside director nomination process than they did during the earlier period. As a further check, we run the same logit regression for non-financial firms in our sample set forth in Table 4.

The findings in Table 4 more or less mirror the findings for financial firms in Table 3. Again, stock returns for both a one- and two-year period are

${ }^{70}$ The empirical question of how director turnover relates to firm performance is complicated by sample selection bias where the key explanatory variable (firm performance) relates to both the probability of a given firm (and hence a director) being in the sample as well as to the outcome of interest (director turnover). This causes the point estimates $(1.22 \%$ and $5.79 \%)$ to be biased, but, in our case, we know the direction of the bias with $1.22 \%$ underestimating and $5.79 \%$ overestimating the true relation. Ideally we could model the sampling process and then correct for the bias in the director turnover equation. The reason we do not correct for the selection process in our analysis is because this type of correction requires the existence of an exogenous variable that explains bankruptcy and/or takeover likelihood but not director turnover. We could not identify such a variable and instead opted to provide estimates of the lower and upper bounds of the true relation between firm performance and turnover. For a discussion of sample selection bias, see JefFrey M. WOOLRIDGE, Econometric ANALYsis of Cross Section and Panel. Data $\$ 17.4 .3$ (2d. ed. 2010) (Binary Response Model with Sample Selection).

${ }^{71}$ See id. 
Table 4: Director Turnover Versus Performance at

Non-FinanCIal Firms

(1)

$-0.122 * * *$

$(0.000)$

Stock return net of market (prior year)

Stock return net of market (prior 2 years)

$-0.207 * * *$

$(0.000)$

Firm size

Years of service

Age 70 and over indicator

$0.053^{* *}$

$(0.021)$

$0.053^{* *}$

$0.031^{* * *}$

$(0.000)$

$(0.021)$

$0.031 * * *$

$1.259^{* * * *}$

$(0.000)$

0.040

(0.822)

Shares held/shares outstanding

$-2.893 * * *$

(0.000)

41902

0.076

$1.262 * * *$

$(0.000)$

0.037

(0.834)

$-2.743 * * *$

(0.000)

Observations

Pseudo R-squared

Note: The logit models in Table 4 include the following non-tabulated controls: years of service and indicators for year, if the director's age is between 65 and 69 , female, audit committee member, compensation committee member, classified board, and whether the appointing CEO is no longer in office. P-values are shown below the logit coefficients with errors clustered at the firm level.

statistically significant. To facilitate understanding of the economic significance of the results, we use Model 1 in Table 4 to estimate the predicted probability of turnover for outside directors at either firms with poor or good financial performance. In this case, we find a one standard deviation change in performance predicts only a $0.68 \%$ increase in turnover probability compared to the $1.22 \%$ probability for financial firms. In unreported regressions, we again examine whether the financial crisis itself produced an increase in turnover for directors at non-financial firms by including an indicator variable for the crisis years, but we do not find any statistically significant results. Firm size is again significant, but this time at the one percent level, while again age has the largest coefficient. And, unlike for financial firms, in unreported findings, audit committee membership is significantly and negatively correlated with turnover at non-financial firms across all specifications.

Finally, consistent with past literature on labor market rewards for directors, ${ }^{72}$ we look to see any effect that home-firm performance had on directors obtaining other board seats in the future. In Table 5, we model each outside director's future number of board seats as a function of prior firm performance at the financial firm in an ordered logit regression. This ap-

\footnotetext{
${ }^{72}$ See, e.g., Yermack, supra note 53, at 2301-04.
} 
proach allows us to investigate whether the directors experience market discipline in future years in the director labor market.

Table 5: Reputation and Total Outside Directorships Held ${ }^{73}$

\begin{tabular}{lcc}
\hline & $(1)$ & $(2)$ \\
\hline Stock return net of market (prior 2 years) & 0.083 & -0.017 \\
& $(0.317)$ & $(0.798)$ \\
Firm size & $0.532^{* * *}$ & $0.184^{* * *}$ \\
Years of service & $(0.000)$ & $(0.000)$ \\
& $-0.025^{* * *}$ & $-0.034^{* * *}$ \\
Age 65-69 indicator & $(0.003)$ & $(0.000)$ \\
& $0.284^{* *}$ & -0.086 \\
Age 70 and over indicator & $(0.010)$ & $(0.385)$ \\
& 0.073 & $-0.407^{* *}$ \\
Female & $(0.705)$ & $(0.010)$ \\
& -0.058 & -0.079 \\
Directorships (t-1) & $(0.709)$ & $(0.564)$ \\
& $3.202^{* * *}$ & \\
Observations & $(0.000)$ & \\
Pseudo R-squared & 5157 & 4881 \\
\hline
\end{tabular}

Note: The ordered logit models in Table 5 include the following non-tabulated controls: indicators for both year and industry. P-values are shown below the logit coefficients with errors clustered at the firm level. Ordered logit cutpoints not tabulated given space constraints.

We find no statistically significant correlation between the performance of the "home" financial firm in the prior two years and future board seats gained in subsequent years. This suggests that other firms are not basing their board appointment decisions on performance at an outside directors' other firms, but rather on other characteristics. Although we obtain qualitatively similar results when we extend the lag to three and four years back, this finding may nevertheless be driven by a longer lag in the market for additional directorships. ${ }^{74}$

\section{Outside Director Pay}

Directors may face market discipline through factors other than turnover. We next explore whether director pay varies at banks and financial firms based on firm performance. Chart II sets forth the mean compensation of outside directors during the sample period, as well as the means of its components.

\footnotetext{
${ }^{73}$ For this table, we use RiskMetrics data, which tracks major directorships held for the directors in its database.

${ }^{74}$ See Yermack, supra note 53, at 2303 (finding a significant link between home firm performance and future directorships gained but only when using four years of lagged returns).
} 
Chart II: Outside Director Compensation at Financial Firms $(\$ 1,000)$

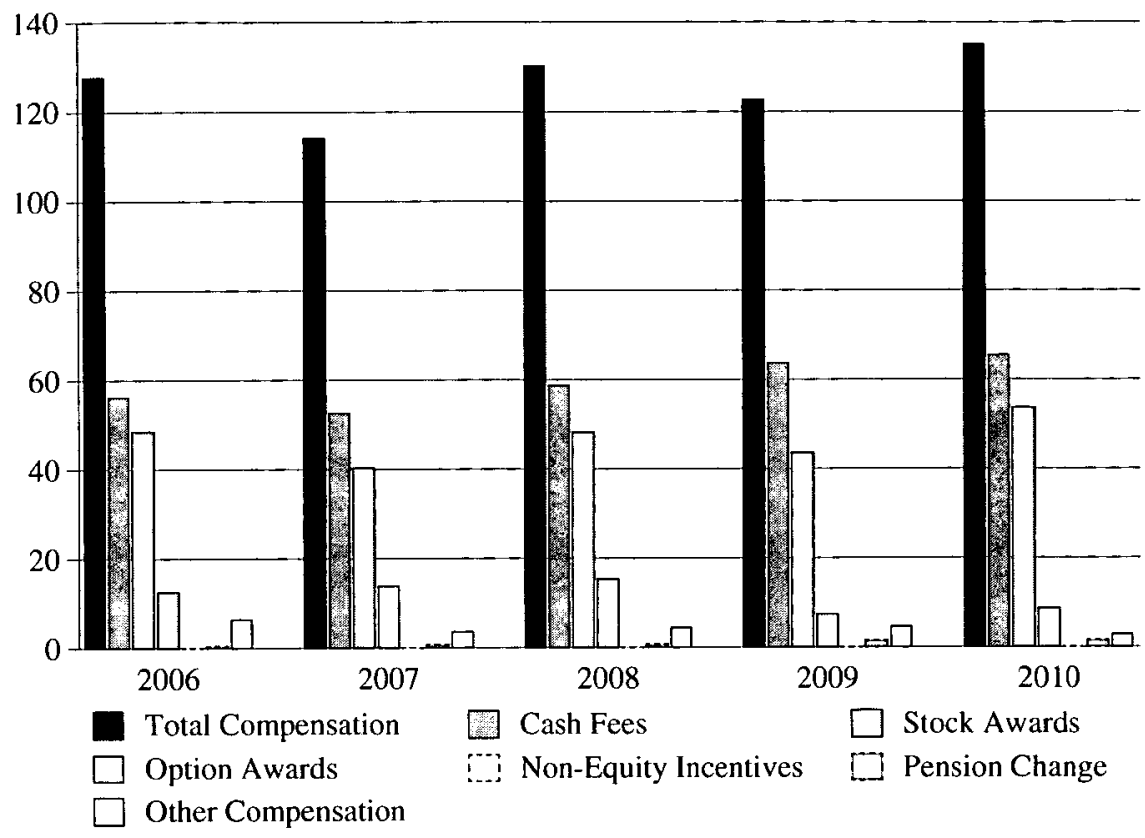

Mean director pay in 2006 equaled $\$ 128,452$ and fluctuated year-overyear before spiking to $\$ 135,750$ in 2010 . The numbers are largely similar for median pay. Median pay in 2006 was $\$ 100,354$, fluctuating year-over-year before spiking to $\$ 114,892$ in 2010 .

The descriptive statistics in Chart II do not, at first blush, seem to be significant year-over-year. They do not show any consistent pattern related to the financial crisis or otherwise to firm performance. In Table 6, we perform an ordinary least squares regression of outside director compensation against control variables reflecting firm performance, firm size, and years of service. 
Table 6: Director Pay versus Performance at Financial Firms ${ }^{75}$

\begin{tabular}{lcccc}
\hline & $(1)$ & $(2)$ & $(3)$ & $(4)$ \\
\hline Stock return net of market (prior year) & -0.017 & & & \\
& $(0.571)$ & & \\
Stock return net of market (prior 2 years) & & -0.020 & & \\
& & $(0.618)$ & & \\
& & & -0.041 & \\
Stock return net of peers (prior year) & & & $-0.564)$ & \\
& & & $(0.745)$ \\
Stock return net of peers (prior 2 years) & & & & \\
& & & & \\
& & & & \\
Firm size & $(0.000)$ & $(0.000)$ & $(0.000)$ & $(0.000)$ \\
& $0.011^{* * *}$ & $0.011^{* * *}$ & $0.011^{* * *}$ & $0.011^{* * *}$ \\
Years of service & $(0.000)$ & $(0.000)$ & $(0.000)$ & $(0.000)$ \\
& $2.406^{* * *}$ & $2.412^{* * *}$ & $2.406^{* * *}$ & $2.409^{* * *}$ \\
Constant & $(0.000)$ & $(0.000)$ & $(0.000)$ & $(0.000)$ \\
\hline Observations & 5399 & 5399 & 5399 & 5399 \\
Adjusted R-squared & 0.416 & 0.416 & 0.416 & 0.416 \\
\hline
\end{tabular}

Note: The regression models in Table 6 include the following non-tabulated controls: indicators for both year and industry. P-values are shown below the regression coefficients with errors clustered at the firm level.

We find no significant correlation between outside director pay and firm performance across any measure of financial firm performance. Instead, we find that director pay is affected by firm size and years of service. ${ }^{76}$ These findings are consistent with other studies that have found director pay to be largely correlated with firm size, to the extent there is any relationship between director pay and other variables other than the general market for director pay. ${ }^{77}$ They diverge, however, from our larger sample of non-financial firms where we find outside director pay awards were correlated with one- and two-year stock performance. In unreported results we further explore the relationship between director pay and financial firm performance by conducting regressions with the change in outside director compensation as the dependent variable. In these regressions, we again find no further evidence of a link between firm performance and director compensation at financial firms.

Though we ultimately find no link between pay and performance for directors at financial firms, this does not contradict Yermack's earlier findings that pay does incentivize outside directors..$^{78}$ The incentives may instead exist through performance-related pay documented in Table 2 . Our analysis shows, however, that the incentives arrive ex ante in the form of compensafirm size.

${ }^{75}$ Because of the strong right skew, we take the natural log of both total compensation and

${ }^{76}$ This result is similar to Yermack's. See Yermack, supra note 53, at 2290.

${ }^{77}$ See, e.g., Stephen Bryan, et al., Compensation of Outside Directors: An Empirical Analysis of Economic Determinants 16 (N.Y.U. Working Paper Grp., Paper No. 2451/27453, 2000), available at http://papers.ssm.com/sol3/papers.cfm?abstract_id=1280674.

${ }^{78}$ See Yermack, supra note 53, at 2286-91. 
tion rather than ex post through compensation adjustment, at least at financial firms.

\section{The Special Case of TARP}

Finally, in Table 7 we analyze the particular case of banks and financial firms which participated in the Troubled Assets Recovery Plan known as "TARP." This extremely controversial plan was made possible by the Emergency Economic Stabilization Act of 2008 enacted in the midst of the financial crisis which allocated $\$ 700$ billion to assist financial firms. ${ }^{79}$ The initial legislation provided wide discretion to the Treasury Department to decide how the money would be provided to the financial community. The Treasury Department finally adopted TARP which provided for investments in applicable financial institutions. ${ }^{80}$ Except for the nine largest financial firms, participation in the TARP program was effectively voluntary. Thus, the decision to receive these funds was a highly salient event, perhaps indicating financial problems at the firm. ${ }^{81}$ In addition, there is evidence that as time passed financially-sounder firms repaid TARP funds earlier in part to avoid its compensation restrictions. ${ }^{82}$

In Table 7 we model outside director turnover as a function of variables reflecting participation in the TARP program. In these logit models, we also include identical variables from Table 3 for control purposes.

In Table 7 we find no significant relationship between TARP participation and outside director turnover. In unreported regressions, we look at the time to repay TARP fund repayments and also find no statistically significant relationship between delayed repayment and director turnover. We look at this alternative indicator because there is some evidence that firms that were slow to repay TARP funds have been viewed as particularly poor performers. Instead, firm size, director age, and, in some cases, firm performance become significant. ${ }^{83} \mathrm{We}$ are thus unable to determine that participation in TARP in the short- or long-term affected director turnover.

${ }^{79}$ Emergency Economic Stabilization Act of 2008, Pub. L. No. 110-343, § 101(a)(1), 122 Stat 3767 (to be codified at 12 U.S.C. $\$ 5211$ ).

${ }^{80}$ See Steven M. Davidoff \& David Zaring, Regulation by Deal: The Government's Response to the Financial Crisis, 61 Admin. L. Rev. 463, 518-25 (2009).

${ }^{81}$ There are countervailing stories. The capital was quite cheap and at least initially banks and financial firms widely participated such that being a part of the program may not have carried much stigma. Id. at 528 .

82 See Baird Webel, Cong. Research Serv., R41427, Troubled Asset Relief ProGRAM (TARP): ImPlementation AND STATUS 13 (2012). See generally Christian Farruggio et al., The Light and Dark Side of TARP, 37 J. BANkING \& Fin. 2586 (2013); Linus Wilson, TARP's Deadbeat Banks, 41 Rev. QuantrTative Fin. \& Accr. 651.

${ }^{83}$ In unreported results, we also find compensation committee membership to be significant at the 5\% level. 
Table 7: The TARP Program and Director Turnover and

Pay at Financial Firms

\begin{tabular}{lccc}
\hline & $(1)$ & $(2)$ & $(3)$ \\
\hline TARP recipient & 0.108 & 0.013 & -0.023 \\
& $(0.585)$ & $(0.948)$ & $(0.909)$ \\
Stock return net of market (current year) & -0.076 & & \\
& $(0.480)$ & & \\
Stock return net of market (prior year) & & $-0.336^{* *}$ & \\
& & $(0.016)$ & \\
Stock return net of market (prior 2 years) & & & $-0.560^{* * *}$ \\
Firm size & $0.145^{*}$ & $0.134^{*}$ & $(0.002)$ \\
& $(0.057)$ & $(0.059)$ & $0.131^{*}$ \\
Age 70 and over indicator & $1.306^{* * *}$ & $1.306^{* * *}$ & $1.303^{* * *}$ \\
& $(0.000)$ & $(0.000)$ & $(0.000)$ \\
Shares held/shares outstanding & 0.275 & -0.354 & -0.564 \\
& $(0.951)$ & $(0.935)$ & $(0.896)$ \\
Constant & $-3.887^{* * *}$ & $-3.993^{* * *}$ & $-4.060^{* * *}$ \\
& $(0.000)$ & $(0.000)$ & $(0.000)$ \\
\hline Observations & 2941 & 2941 & 2941 \\
Pseudo R-squared & 0.077 & 0.084 & 0.085 \\
\hline
\end{tabular}

Note: The logit models in Table 7 include the following non-tabulated controls: years of service and indicators for year, if the director's age is between 65 and 69 , female, audit committee member, compensation committee member, classified board, and whether the appointing CEO is no longer in office. P-values are shown below the logit coefficients with errors clustered at the firm level.

\section{IMPLICATIONS}

We thus find evidence of a statistically significant but relatively weak economic relationship between labor market discipline for outside directors and firm performance. This finding is subject to the caveat that interpreting outside directors at acquired and reorganized firms as "turned over" substantially increases the economic significance of firm performance to turnover, a point we address further below. What is more, outside director pay awards seem completely insensitive to firm performance. In both cases, the salience of TARP-recipient status seems to have had no significant effect either on director turnover or pay.

Our findings are subject to multiple interpretations for board-centered financial regulatory reform. They all share the common implication, however, that board-centered reform is unlikely to be effective if a penal labor market is an important predicate. There does not appear to be a viable labor market for outside directors to sufficiently motivate them to act in the ways regulators and perhaps shareholders might desire. Nor do compensation 
practices appear to be self-correcting, at least beyond discipline imposed by the equity incentives built into existing pay structures.

\section{A. The Principal Case}

The lack of an effective disciplinary market for directors even in the salient circumstances of the financial crisis is perhaps not surprising. Director elections have been strongly criticized as ineffective disciplinary devices, beset by structural problems. ${ }^{84}$ In particular, potential activists bear all of the costs of mounting a proxy contest while realizing only a portion of uncertain gains to discipline ${ }^{85}$ More relevantly, other than a handful of activist hedge funds, most shareholders, including institutions, appear extremely sensitive to such costs. Withhold-the-vote campaigns and the various iterations of proxy access reduce the costs involved, ${ }^{86}$ but the calculus remains largely unchanged. ${ }^{87}$

The phenomenon may be more pronounced to the extent that financial firms have fewer large blockholders ${ }^{88}$ thereby reducing the gains to activism. Activist hedge funds and investors regularly run proxy contests extending to about one to three percent of public companies in a given year. ${ }^{89}$ These do arguably function as an effective check on firm performance in a small number of cases. This may have wider market effects generally as firms take ex ante steps to prevent being targeted by activist shareholders. Yet, in the case of S\&P 1500 financial and bank firms, this activism is quite limited due to Federal Reserve regulations which serve to entrench boards of directors and damper activism in this arena. ${ }^{90}$ According to FactSet Shark Repellent, only seven national commercial banks were targeted by activist campaigns in the S\&P 1500 during our sample period. Not surprisingly, these were the largest and most salient institutions, including Bank of

${ }^{84}$ See, e.g., Lucian A. Bebchuk, The Myth of the Shareholder Franchise, 93 VA. L. REv. 675, 682-86 (2007). For criticism of Bebchuk's analysis, see generally Martin Lipton \& William Savitt, The Many Myths of Lucian Bebchuk, 93 VA. L. REV. 733 (2007); Lynn A. Stout, The Mythical Benefits of Shareholder Control, 93 V^. L. Rev. 789 (2007).

${ }^{85}$ Bebchuk, supra note 84, at 689. These costs tend to rise depending upon the size of the firm. See Marcel Kahan \& Edward Rock, The Insignificance of Proxy Access, 97 VA. L. REv. 1347, 1365 (2011).

${ }_{86}^{86 e}$ Kahan \& Rock, supra note 85 , at 1384-91.

${ }^{87}$ Id. at $1390-92$ (noting that campaign costs are the most significant expense for activists and are not reduced in either case). Kahan and Rock do note that proxy contexts have generally tended upwards, with fifty-seven taking place in $2009 . I d$. at 1364.

${ }^{88}$ See Renee Adams \& Hamid Mehran, Is Corporate Governance Different for Bank Holding Companies?, 9 ECON. Pol.'Y Rev. 123, 133-34 (2003) (finding higher institutional ownership of manufacturing firms than bank holding companies).

${ }^{89}$ FactSet SharkRepellent Database (search results on file with authors).

${ }^{90}$ See Policy Statement on Equity Investments in Banks and Bank Holding Companies, 12 C.F.R. 225.144 (2008). See generally Steven M. Davidoff, In Blocking Activists, the Fed Protects Poorly Performing Banks, N.Y. Times DealBook (May 8, 2012, 6:11 PM), http:// dealbook.nytimes.com/2012/05/08/in-blocking-activists-the-fed-protects-poorly-performingbanks/. 
America, Citigroup, JPMorgan Chase, Wachovia, and Wells Fargo. It may be that activism can function as a disciplinary mechanism in some circumstances for financial firms, but we do not believe it to be a significant factor in our sample despite the prominence of the recent campaign at JPMorgan Chase.

On the other hand, many financial firm boards serve at the whim of not only shareholders but also financial regulators. During the period preceding the crisis, boards had been at least nominally charged by various regulators with managing risk at financial firms. ${ }^{91}$ And there is evidence that with respect to Bank of America and Citigroup, the Treasury Department, Federal Reserve, and bank regulators acted to discipline the board, replacing a number of directors. ${ }^{92}$ But it appears from our sample that this disciplinary action did not extend to smaller financial firms in the S\&P 1500. This is not surprising, as regulatory action directed against boards is unlikely unless the bank is in clear financial distress, not merely poorly performing.

Ultimately, our findings may provide ammunition for those who want to enhance labor market discipline for directors more generally. Enhanced discipline of this sort could take a variety of forms. Obviously, federal bank regulators themselves might require more of boards in managing risk with regulatory action as a penalty. As noted, bank regulators currently have substantial power to supervise, remove, and replace directors. ${ }^{93}$ Proxy access and similar reforms that would lower the cost of shareholder activism are also potential avenues. But changes to the director election system may prove insignificant in ameliorating the incentive structure for shareholder activism. ${ }^{94}$ And regulatory barriers in the banking context may limit their effect anyway. More robust enforcement of fiduciary duties might serve as a substitute for labor market discipline, ${ }^{95}$ though most of the post-crisis reforms have been generated at the national level, while fiduciary duty law

${ }^{91}$ See Paul L. Lee, Risk Management and the Role of the Board of Directors: Regulatory Expectations and Shareholder Actions, 125 BANKING L.J. 679, 681-89 (2008)

${ }^{92}$ See Dan Fitzpatrick \& Damian Paletta, BofA Urged by Regulators to Revamp Board of Directors, WALL. ST. J., May 15, 2009, available at hitp://online.wsj.com/news/articles/ SB 124235572006122687; Deborah Solomon \& David Enrich, U.S. to Take Big Citi Stake and Overhaul the Board, WAL. ST. J., Feb. 27, 2009, available at http://online.wsj.com/news/articles/SB123573611480193881.

${ }^{93}$ See Office of Comptroller of The Currency, The Director's Book: The Rol.e of A NATIONAL DireCTOR 101-02 (Oct. 2010), available at http://www.occ.gov/publications/publications-by-type/other-publications-reports/The-Directors-Book.pdf.

${ }^{94}$ See Kahan \& Rock, supra note 85, at 1384-93 (questioning the incremental cost savings associated with proxy access).

${ }^{95}$ But see In re Citigroup Inc. S'holder Derivative Litig., 964 A.2d 106, 131 (Del. Ch. 2009) ("There are significant differences between failing to oversee employee fraudulent or criminal conduct and failing to recognize the extent of a Company's business risk. Directors should, indeed must under Delaware law, ensure that reasonable information and reporting systems exist that would put them on notice of fraudulent or criminal conduct within the company."); Robert T. Miller, Oversight Liability for Risk-Management Failures at Financial Firms, 84 S. CAl. L. Rev. 47, 102-20 (2010) (arguing against expanded fiduciary duty liability for risk management oversight). 
remains a state law issue. ${ }^{96}$ This creates a coordination problem at a minimum. There are thus a number of potential options for reforming the director labor market, each with their own benefits and costs. We do not argue here that such reforms are appropriate. For our purposes, it is enough to say that board-centered financial reform is likely to be ineffective without additional measures to enhance discipline for poorly performing outside directors.

As noted, we find that outside directors faced economically significant consequences for poor firm performance if we consider directors at acquired and bankrupt firms as "turned over." The prospect of losing a board position based on acquisition or bankruptcy may complement the weak shareholder- and regulator-imposed discipline discussed above such that boardcentered financial reform remains a viable choice. But such a view requires relatively heroic assumptions about the nature of the acquisitions we observe which make up the lion's share of the dropped firms. While some of these acquired firms were in serious distress, it is hard to characterize the loss of outside director positions they occasioned to be disciplinary in any significant manner.

\section{B. The Pessimistic Case}

Measures to ratchet up discipline of outside directors may do harm, ${ }^{97}$ and at the same time they may do very little good. An alternative interpretation of our data is that it is consistent with the proposition that outside director behavior is generally unrelated to firm performance. The structural attack on the independent board's consequentiality for firm performance has occurred on multiple fronts, and often in the service of distinct arguments. ${ }^{98}$ Nevertheless, they collectively share a skeptical view of outside directors' basic capacity to shape firm behavior. Our findings could be read to suggest that investors (and perhaps regulators) largely share that skepticism.

Most famously, there is a well-recognized limitation on the ability of (1) "monitoring" directors to help manage a firm and (2) "managing" directors to monitor executives and other directors. ${ }^{99}$ Monitoring directors may be unhelpfully committed to failed strategies that they helped implement in

${ }^{96}$ But see John Armour and Jeffrey Gordon, Systemic Harms and Shareholder Value 32 (Columbia Law \& Econ. Working Paper Grp., Paper No. 452, 2013), available at http:/papers. ssrn.com/sol3/papers.cfm?abstract_id $=2307959$ (suggesting that the business judgment rule be cut back for outside directors at SIFIs while capping potential liability at a multiple of recent director compensation).

${ }^{97}$ See Yermack, supra note 53, at 2296-97.

${ }^{98}$ For more summaries of this view, see generally Kelli A. Alces, Beyond the Board of Directors, 46 WAKE Forest L. Rev. 783 (2011) (arguing to replace the board); Lisa M. Fairfax, The Uneasy Case for the Inside Director, 96 lowa L. Rev. 127 (2010) (arguing to add more inside directors to the board).

${ }^{99}$ See generally Jonathan R. Macey, Corporate Governance: Promises Kert, Promises Broken 53-68 (2008); Miriam Schwartz-Ziv \& Michael Weisbach, What Do Boards Really Do? Evidence from Minutes of Board Meetings, 108 J. FIN. Econ. 349 (2013). 
their managing capacity. ${ }^{100}$ Certain traits, e.g., independence or not, may be helpful for a monitor, but not a manager, and vice versa. ${ }^{101}$ Finally, executives may adjust their behavior depending on the level of a board's monitoring and thereby thwart the board's ability to co-manage. ${ }^{102}$ Jill Fisch has gone so far as to state that the choice of a monitoring board over a managing one has delinked board performance from firm performance, at least in noncrisis situations. ${ }^{103}$

Not only might boards be unable to perform a monitoring and managing function simultaneously, they might not be able to perform either function in anything but the most cabined fashion. ${ }^{104}$ On the one hand, even independent boards might be subject to capture by executives. ${ }^{105}$ On the other hand, boards, and especially outside directors, may always be at too great of an informational distance to perform sufficient ex ante monitoring of those executives. ${ }^{106}$

If true, this account leads to the conclusion that it would be senseless for investors or regulators to hold outside directors responsible for financial

${ }^{100}$ See MACEY, supra note 99 , at 54.

101 See Jill E. Fisch, Taking Boards Seriously, 19 Cardozo L. Rev. 265, 280-82 (1997). (2007).

${ }^{102}$ See Renee Adams \& Daniel Ferreira, A Theory of Friendly Boards, 62 J. FIN. 217, 231

${ }^{103}$ See Jill E. Fisch, The Overstated Promise of Corporate Governance, 77 U. CHI. L. Rev. 923, 929 (2010) ("As a result, large-scale empirical studies are unlikely to find a link between board monitoring and firm performance. Rather, monitoring boards are likely to provide the most value in deterring managerial self-dealing and responding to crises.") (footnote omitted).

${ }^{104}$ See, e.g., Colin B. Carter \& Jay W. Lorsch, Back to the Drawing Bonkd: DeSigning CoRPorate BoARds For a COMPLEX WORLd 25 (2003).

${ }^{105}$ See, e.g., MACEy, supra note 99, at 57-60; LuCian Bebchuk \& Jesse Fried, supra note 41 , at 25-26. Moreover, there is at least some empirical evidence that aggressive monitoring leads to penalties in the director labor market, consistent with the view that executives remain central to the nominating process. See Mary-Hunter McDonnell \& Brayden King, The Market Hates a Monitor: The Adverse Selection of Independent Directors Who Oust a CEO 16-18 (Jul. 23, 2011) (unpublished manuscript), available at http://papers.ssrn.com/sol3/papers.cfm?abstract_id $=1893713$. On the other hand, the proliferation of nominating committees and other forces seems to have removed at least some of this control from the hands of CEOs. See, e.g., Marcel Kahan \& Edward Rock, Embattled CEOs, 88 TEx. L. REv. 987, 1026-32 (2010).

${ }^{106}$ See, e.g., Ran Duchin, John G. Matsusaka \& Oguzhan Ozbas, When Are Outside Directors Effective?, 96 J. Fin. ECON. 195, 196 (2009); James D. Cox, Managing and Monitoring Conflicts of Interests: Empowering the Outside Directors with Independent Counsel, 48 VILL. L. REv. 1077, 1082 (2003); Michael C. Jensen, The Modern Industrial Revolution, Exit, and the Failure of Internal Control Systems, 48 J. FIN. 831, 864 (1993). Furthermore, outside directors at financial firms may suffer more than those in other industries. There is serious concern that even executives were unable or unwilling to appreciate the level of risk being taken by their subordinates at financial firms. See Steven L. Schwarcz, Conflicts and Financial Collapse: The Problem of Secondary-Management Agency Costs, 26 YALE. J. REG. 457, 461-64 (2009) (observing that the complexity of financial transactions entered into by secondary employees disabled top management from properly evaluating firm risk). But see Steven M. Davidoff \& Claire Hill, Limits of Disclosure, 36 SEATTLE L. Rev. 599, 600-03 (2013) (arguing that complexity of financial instruments was not an observable defect for investors). It stands to reason that outside directors would be in an even worse position to manage that risk in the face of more significant positional deficits. 
firm performance given the insurmountable structural disadvantages they face. ${ }^{107}$ Accordingly, the absence of labor market discipline for poor financial firm performance would be unsurprising. Moreover, board-centered responses to financial firm problems are likely to be ineffectual.

On this interpretation, the increased economic significance of performance for outside director turnover we observe when we include acquired or bankrupt firms does not change anything. The fact that those outside directors lost their positions in such a process is to be expected; it does not imply that anyone believed them to be consequential. Thus, even the assumptions regarding the acquisitions in our sample do not refute the argument that outside directors are poor focal points for effective financial regulation.

Of course, even if outside directors are currently irrelevant, regulatory steps taken to push them further towards, for instance, a risk management function may provide a shock that might cure some of the deficits outside directors face, making outside director responsibility more plausible going forward. Perhaps these reforms might focus director attention on tasks they might have otherwise disregarded, irrespective of the labor market consequences. ${ }^{108}$ We would merely observe that none of the most popular boardcentered proposals truly alter the outside directors' relationship with the firm. We find little in the history of corporate governance or the academic literature on organizational behavior to suggest that in the absence of a change of incentives, the mere creation of, for example, a risk management committee populated by outside directors will change financial firm governance. ${ }^{109}$ The same could be said of other board-centered corporate governance reforms of recent memory involving compensation and auditor supervision.

Otherwise, the introduction of new board-centered mandates might also highlight outside director functions in shareholders' or regulators' eyes and thereby indirectly increase future labor market discipline despite their inconsequentiality. That threat might encourage outside directors to assume a more effectual role in financial firms. There is some data, including our re-

${ }^{107}$ See MACEY, supra note 99, at 80. ("The most important corporate governance lesson to be learned from Enron is that it is unwise to place too much trust and reliance on a company's board of directors.").

${ }^{108}$ See, e.g., Melvin Aron Eisenberg, New Modes of Discourse in the Corporate Law Literature, 52 GEo. WASH. L. REv. 582, 589-90 (1984) ("The function of corporate law in the conflict-of-interest area is not to forcibly redirect evil human nature onto the path of good, but to reinforce and give greater precision to the general inclination to do right ....."); Edward B. Rock, Saints and Sinners: How Does Delaware Corporate Law Work?, 44 UCLA L. REv. 1009, 1104 (1999) (suggesting judicially-established norms might be internalized by directors despite the absence of serious legal sanctions).

${ }^{109}$ Admittedly, this is a controversial assertion. Yet, the empirical evidence supporting outside directors is based on observed effects rather than observations of the internal workings of such organs. See Michael S. Weisbach \& Benjamin E. Hermalin, Boards of Directors as an Endogenously Determined Institution: A Survey of the Economic Literature 11-14 (June 15, 2000) (working paper), available at http://papers.ssm.com/abstract $=233111$. While we are aware of the literature on decision-making and heterogeneity, we see no reason to believe why this is a result of outside directors rather than simple board composition. 
sults from unreported regressions, indicating that shareholders hold compensation and audit committee members more accountable post-crisis than other outside directors. ${ }^{110}$ Two caveats should be noted, however. First, it is unclear whether the regulatory mandates regarding audit committees and compensation committees set the stage for shareholder discipline rather than being endogenously driven by the salience of recent compensation and accounting scandals. If so, board-centered risk management reforms are somewhat beside the point, as outside directors would be held responsible going forward anyway. Second, the risk management function appears more timeconsuming and complicated than the compensation function, and the former is more likely to run into conflicts of interest with insiders than the audit function. Therefore, it is less obvious why shareholders would expect the same level of outside director competence with respect to risk management.

\section{The Case of Shareholder Forbearance}

Finally, it may be that investors and regulators accept outside directors' importance to financial firm performance, and are willing to discipline those directors despite its costs, but nevertheless chose not to do so in the era of the financial crisis. For instance, there may be a disconnect between shareholders' risk preferences and those of reformers. To the extent that the boardcentered responses have looked to risk-dampening as a goal, shareholders may not share the same wishes. Shareholders at highly-leveraged financial firms are understood to prefer risk, certainly relative to regulators who essentially serve as creditor monitors. ${ }^{111}$ Diversified shareholders may internalize the costs of systemic risk occasioned by risk taking at particular firms, ${ }^{112}$ but the matter is far from settled. Assuming that shareholders understood the actions and inaction of outside directors leading up to the financial crisis, the failure of shareholders to discipline them might become understandable as an enlightened response to a complicated set of events. During that time, outside directors actually performed well from the shareholder perspective, admittedly with unfortunate consequences. In this scenario, boards are viewed as consequential and responsive to shareholder concerns, just not in a social welfare enhancing way that regulators value.

We are uncertain whether shareholders fully comprehended this risk, so we are hesitant to assign much weight to this explanation. Moreover, descriptive statistics show that director turnover rates for poor performance were even lower prior to the financial crisis, implying that shareholders generally were not imposing any type of labor market penalties. Nonetheless, it

${ }^{110}$ See, e.g., Yermack, supra note 53, at 2293 (compensation committees); Fich \& Shivdasani, supra note 44, at 331 (audit committee in the wake of fraud); Srinivasan, supra note 44, at 294 (same).

II' See, e.g., Frederick Tung, Pay for Banker Performance: Structuring Executive Compensation for Risk Regulation, 105 Nw. U. L. REV. 1205, 1210 (2011).

112 See Gordon, supra note 26, at 1-2. 
is a plausible explanation, which, if true, would raise a host of issues for any financial reform that implicitly or explicitly relied on shareholder action. A principal issue, for example, is the likelihood that director-centered reform may be counteracted by shareholders who prefer a different outcome than reformers.

Alternatively, investors and regulators may view the financial crisis as a random event that could not have been reasonably predicted by outside directors. Accordingly, they may have chosen to give outside directors a "pass" for poor firm performance during the crisis. This seems plausible, but it also suggests that board-centered reform is unlikely to effectively prevent future crises.

\section{Conclusion}

We are thus left with mostly negative conclusions from our data. If post-financial crisis board-centered reform for financial and other firms relies on the discipline of a director labor market to reshape outside director behavior, it is not supported by our findings absent some heroic assumptions about firms dropped from our sample. In fairness, though, these reforms have never been explicitly based on such a premise. Our data also leaves viable alternate theories that boards are either inconsequential or that any of their crisis-related failings were insignificant. Alternatively, shareholders may simply not be acting to effectuate change for other reasons.

On the basis of these findings, we conclude as follows. First, to the extent board-centered post-financial crisis reforms depend upon a labor market for directors, our findings show that they are likely doomed to fail absent significant changes to that market. Second, our findings, in the context of uncertainty regarding board consequentiality, give one pause when attempting to gauge the effect of board-centered financial crisis reform. Our findings are thus cause for skepticism to the extent reform has focused on board change as a remedy for perceived failings in the years leading up to the financial crisis. Further empirical study of the divergent explanations of our data is necessary before the wholesale reforms that have empowered outside directors can be justified. 
